\title{
An-Natiq
}

Jurnal Kajian Islam Interdisipliner

Volume 01 Nomor 02 Tahun 2021

e-ISSN: 2777-0176 | p-ISSN: 2798-0200

\section{THE EXISTENCE OF EQUALITY EDUCATION SYSTEM IN PESANTREN SALAFIYAH}

\author{
Asrizal Saiin \\ STAIN Sultan Abdurrahman Kepulauan Riau \\ e-mail: asrizal@stainkepri.ac.id
}

\begin{abstract}
The study in this manuscript discusses the impact on the educational equalization system of Pesantren Salafiyah and designs how Pesantren Salafiyah has always existed in the world of modern education. This research belongs to the type of qualitative study using the document analysis method. The form of data analysis used is descriptive analysis. The research approach method in this paper is library research. This study is divided into four methods, namely, the method of determining the subject, the form of the study, the method of data collection, and the method of data analysis. The result is the ability of Pesantren Salafiyah to make certain accommodations and concessions to find a pattern that they consider appropriate enough to face modernization and changes that are increasingly fast and have a broad impact without sacrificing the essence and other basic things in the existence of the pesantren, so that Pesantren Salafiyah still exists in the midst of the hustle and bustle of modernizing Islamic education.
\end{abstract}

Keywords: Existence, Education System, Equality, Pesantren Salafiyah.

\section{A. Introduction}

The oldest Islamic educational institution in Indonesia (indigenous) which was first developed was the pesantren education model. Pesantren existed before Indonesia's independence. Initially, the development of pesantren was only on the island of Java, then spread to almost all of Indonesia. The pesantren education system also has long historical roots and is full of dynamics so that it has brought it to a variety of formats to date.

In general, pesantren can be differentiated into Pesantren 'Salafiyah' and Pesantren 'Khalafiyah'. In a scientific context, Pesantren Salafiyah is one form of pesantren which still maintains the teaching of classical books as the core of its education (Yasmadi, 2002). Disciplines that are not related to religion (general knowledge) are not taught in Pesantren Salafiyah. In addition, the teaching system used is still the classical method. The curriculum at the Pesantren Salafiyah does not use the form of a syllabus, but is in the form of level levels of books in various disciplines, with learning that uses a traditional approach as well. Some traditional Islamic boarding schools do Sufism practices or things that smell like Sufism which have become a subculture of pesantren until now (Hasbullah, 1999).

Pesantren Salafiyah (traditional) are solely run Islamic science curriculum, and teaching general sciences, typically do not also apply the provisions granting 
diplomas, so they do not get the recognition of education the government and employers (Djamas, 2009). As a result, most graduates of Pesantren Salafiyah are not taken into account in modern society. Borrowing the term Nurcholish Madjid, Pesantren Salafiyah serves as a collection of clothing that can not be sold, meaning it can not compete in a global world.

So that in 2018, the Director-General of Islamic Education issued a Decree of the Director-General of Islamic Education Number 3543 of 2018 concerning Technical Guidelines for the Implementation of Equality Education in Pesantren Salafiyah. Equality education at salafiyah boarding schools is an equalization service in education through non-formal education channels aimed at other students, who for various reasons cannot continue their education at the SD/MI, SMP/MTs SMA/MA levels which are formal education, in the end, they continuing education to Pesantren Salafiyah as non-formal education units. The expectation of students who follow the teaching and learning process in Pesantren Salafiyah has the knowledge, skills, and attitudes expressed and recognized equally with graduates SD / MI, SMP / MTs, and SMA / MA / SMK / MAK.

In PMA No. 31 of 2020 Article 4 states that pesantren education is carried out through two channels, namely formal education and non-formal education. While Pesantren Salafiyah entrance to the non-formal education. Based on Law no. 18 the Year 2019 concerning Pesantren, in Article 23, paragraphs 3 and 4 mentioned that graduates Pesantren path of non-formal education is recognized equal to the formal education level at certain after passed the exam, you can then proceed to formal education are higher, both similar or not, and/or job opportunities.

Existence Pesantren Salafiyah in various areas essentially has the experience and their individual stories. equalization program Pesantren Salafiyah with more formal education has made Pesantren Salafiyah are in a selection dilemma. To date, there has been a fierce struggle between maintaining traditionalist education or moving to modernization. Rivalry both lead to a bargain even an exhausting tug of war that until now Pesantren Salafiyah can not exist as other educational pathways.

Based on the background of the problems described above, and given the importance of this issue to be studied, the researchers raised this issue into a study, where this research will discuss the impact on the system of education equivalency Pesantren Salafiyah and designing how Pesantren Salafiyah always exist in the world of modern education.

\section{B. Methods}

The type of research in this paper is a qualitative study using the document analysis method. The method research approach in this paper is library research, a study of texts about the educational equivalency system in Pesantren Salafiyah. Library research utilizes library resources to obtain research data. Strictly speaking, library research limits its activities only to materials from previous research that 
have been recognized without requiring field research. While the research in the field is only as a compliment. While the research method with a qualitative approach is a research and understanding process based on a methodology that investigates a social phenomenon and human problem (Creswell, 1998).

The main purpose of qualitative research is to understand the phenomenon by focusing more on a complete picture of the phenomenon under study rather than breaking it down into interrelated variables. The hope is to gain a deep understanding of the phenomenon under study (Salim, 2001). The form of data analysis used is descriptive analysis. Its movement is not only limited to collecting and compiling data but includes the analysis and interpretation of the data. Fundamentally, it can be said that a description is an objective representation of the phenomenon under study (Surachmad, 1970). This study is divided into four methods, namely, the method of determining the subject, the form of the study, the method of data collection, and the method of data analysis

\section{Results and Discussion}

\section{Definition of Pesantren and its Characteristics}

Pesantren is a form of institutionalized Islamic education in Indonesia. According to Arifin (1993), pesantren is an Islamic religious education institution that is growing and recognized by the people of Indonesia. The system is to have dormitories, where students receive religious education through a recitation system or madrasa which is fully under the leadership of one or several Kiai with charismatic characteristics and is independent in all respects.

Pesantren is a traditional Islamic educational institution to study, understand, explore, appreciate, and practice Islamic teachings by emphasizing the importance of religious morals as guidelines for daily behavior. Therefore, when viewed from the education system, pesantren is an educational institution that is unique to Indonesia. This uniqueness and distinctiveness make it so difficult to provide a representative definition for pesantren.

Pesantren as a religious institution today, still teaches and spreads the knowledge of the traditional Islamic religion. However, modern boarding also continue to develop, where these pesantren do not only teach religion but also teach general sciences, skills, and so on. So it can be concluded that pesantren that are developing in Indonesia are currently divided into two types, namely traditional boarding schools and modern boarding schools.

There are several aspects of pesantren that need to be studied more deeply, seeing that pesantren are part of the culture in the life of the Indonesian people as a nation. This culture can be seen from several criteria that exist in a pesantren, namely: a) the existence of pesantren as an institution 
of life that stores the general pattern of life of the Indonesian nation, b) some supports that become the bones of pesantren life, c) the ongoing process of forming its values in the pesantren, complete with its symbols, d) the existence of an attraction so that the surrounding community considers pesantren as an ideal alternative for the attitude of life that exists in the community itself, e) the development of a process of influence with the community outside, on the formation of new values that are universally acceptable to both parties.

Pesantren which are known to be multicultural and multifunctional have enormous opposition to guarding a civilization that has been lulled by advances in science and technology. Pesantren not only face demands to maintain values and traditions which are the intellectual treasures of Islam but also face globalization that can destroy the critical reasoning of students based on Islam and religion at any time (Abdullah, 2003). The values and traditions of pesantren can be classified into two groups, first, religious values that have absolute truth, and are related to the afterlife. Second, religious values that are relative, empirical, and pragmatic to solve various problems of daily life according to religious law.

Regarding objectives, pesantren are different from other educational institutions, which generally state the goals of education clearly, for example, are formulated in a clear constitution, so pesantren generally do not formulate educational goals. This attitude has been carried away by the simplicity of the pesantren which is following the motivation for the establishment of the pesantren, where the Kiai teaches all his students to learn to worship and is never associated with goals in life or positions in everyday life such as social and economic.

In essence, establishing a pesantren is aimed at spreading the religion and a place to study Islam. Pesantren which aims as an institution for the spread of Islam is to provide a good influence on the surrounding environment so that those who have never previously accepted Islam can change after accepting and even become devout followers of Islam. As for the pesantren which aims as a place to study Islam, because the first activity is to study Islam. This function almost affected the surrounding culture, namely steadfast Muslims, and even gave birth to many scholars who had strong Islamic insights.

Generally, the purpose of pesantren is to develop Muslims to have Muslim personalities, following the teachings of Islam and to instill this religious sense in all aspects of life and to make them useful for religion, society, and the state. While the specific objectives are: a) educating students as members of society to become a Muslim who fears Allah, has a noble character, has intelligence, skills and is mentally healthy as citizens of Pancasila, b) educates students to become Muslim human beings as cadres of scholars who are soulful. sincere, 
steadfast, tough, entrepreneurial in practicing Islamic history as a whole and dynamically (Hasbullah, 2006).

To find out the purpose of pesantren education, the path that must be taken is to understand the functions carried out and developed by the pesantren itself, both concerning santri, Kiai, and with the surrounding community. However, pesantren as an educational institution does not have a clear purpose, both in the institutional, curricular and general and special instructional settings. The goals that are owned are only hopes and desires that can be achieved, both for Islamic boarding schools, students, Kiai, and the community.

\section{Overview of the Pesantren Salafiyah}

Pesantren Salafiyah is seen as indigenous education in Indonesia. In terminological, Pesantren Salafiyah is typical Indonesian Islamic educational institutions (indigenous) are cared for by clerics who have charismatic using the hostel system with methods of learning takes place in the form of wetonan, sorogan and memorizing. The study period is adjusted to the number of classic books studied by students whose main purpose is moral development and religious mission (Sutrisno, 2013). Previously, this pesantren was founded by the guardians to teach Islamic teachings to their followers who came from various regions. After they finished studying Islamic religion, they returned to their place of origin and then taught back what they had learned to their students, so that this pesantren developed as an educational institution that specifically teaches religious sciences (tafaqquh fiddin) until now.

Pesantren Salafiyah or shortened to Salaf or Salafi is pesantren institutions that still retains the pattern of education traditional pesantren which is reflected in the curriculum that teaches the classics (kitab kuning) alone, learning model centered on the chaplain, and also other things which still maintains the old pesantren tradition. With this simple and traditional educational condition, he lives in a society that is getting more advanced with a variety of modern and diverse educational service options. Not only that, systemically, the western media makes negative news that this pesantren is considered a militant and radical Islamic cadre institution.

This Pesantren Salafi has a uniqueness that seems to be maintained by its Kiai as he had experienced when he lived in a boarding school. Some of the uniqueness that can be identified include (1) Kobong, which is the residence of students. (2) the mosque as a center for worship and teaching and learning including also functions as a place for i'tikaf and doing exercises, suluk, and dhikr, as well as other practices in the life of the tarekat and Sufis, as well as (3) Santri, which consists of santri muqim and santri kalong (not lodged). (4) Kiai is a central figure in the field of religious knowledge, a teacher who teaches 
classical books or the yellow book and at the same time the owner of a pesantren. (5) Classical books (ancient) are books written by previous scholars. (6) Traditional learning methods are recitations sorogan and bandungan (wetonan).

The values taught by the Kiai to his students have built trust, commitment, and high loyalty to the Kiai and the pesantren, in addition to the ability of the pesantren to make certain accommodations and concessions to find a pattern that he deems appropriate enough to face modernization and changes that are increasingly fast and difficult. wide impact without sacrificing the essentials and other basic things in the existence of pesantren, so Pesantren Salafiyah still exists amid the bustle of the modernization of Islamic education and also the challenges of public education a very promising future success of children (Luthans, 2006).

With a variety of challenges mentioned above, Pesantren Salafiyah exists with a specific culture. The hypothesis, resilience Pesantren Salafiyah is rooted in strong culture and rooted in the community. Of course, it is interesting to examine the resilience of Pesantren Salafiyah in the face of a wave of modernization of education, especially in terms of modern boarding organizational culture.

\section{Integration System Education Salafiyah with System Education Modern}

In connection with the educational system Pesantren Salafiyah, as traditional Islamic educational institutions, can be seen from the two senses, the sense of the physical aspect/building and in terms of cultural understanding. From a physical point of view, pesantren is an educational complex consisting of at least five basic elements, namely residence, mosque, santri, the teaching of classical books, and Kiai (Djamas, 2009). Teaching methods in Islamic boarding schools also have their characteristics such as the method wetonan (bandongan), sorogan, memorizing (tahfizh), mudzakaroh (deliberation), munazharah, lectures, and others (Suwito and Fauzan, 2004).

From a cultural point of view, pesantren includes a broader understanding, starting from the distinctive value system that is intrinsically embedded in the pattern of life of the santri community, such as obedience to the Kiai as the central figure, sincere and attitude humble, and religious traditions that are passed down from generation to generation. Due to the unique life of the pesantren, Abdurrahman Wahid placed the position of pesantren as a sub-culture, with three main elements forming (sub-culture) pesantren, namely: independent pesantren leadership, books that became general references that lasted from time to time, and the system of Islamic education. values used in the pesantren environment. The main values that become sub-cultures in the life of the pesantren are strongly influenced by the 
provisions of fiqh, then the values of Sufism which are practiced in the form of the main practice (fadhailul 'amal), and Ash'ari theology or ahl al-sunnah wa al-jama'ah (Djamas, 2009).

Pesantren Salafiyah is the Islamic educational institutions which focusing on religious guidance and orientation alone hereafter. The religious paradigm that developed in these educational institutions then developed into dogmatic teachings and tended to be mystical, so that what emerged later was the face of a fatalistic society (jabariyah). In subsequent developments, the paradigm began to change along with the social conditions of society that were practical, pragmatic, and materialistic as the implications of modernity. So that in this era what is needed is not only good morals or morals but also skills and skills that are relevant to work needs.

There are several phenomena related to Pesantren Salafiyah when dealing with modernity: a) Pesantren Salafiyah stick with the system traditional, b) Pesantren Salafiyah disappeared supplanted by the modern education system, c) Pesantren Salafiyah transformed into public education institutions, d) Pesantren Salafiyah adapts and adopt more or less modern educational content and methodologies while trying to maintain its identity.

In this regard, Azyumardi Azra suggested that the Pesantren Salafiyah should cultivate a proper appreciation of all developments occurring in the present and the future so that it can reproduce prospective ulama who are broad-minded, while also being committed to maintaining their traditional functions (Azra, 2012). Therefore, the principle that is held in the renewal (modernization) of the pesantren education system is that it must still consider aspects of its identity so that its traditions which are still considered relevant are maintained. This is in line with the task of Islamic educational institutions as a medium for developing the potential of students who continue to experience changes as well as a medium for cultural inheritance as explained above.

It is understood that ideally, the interaction between traditionalism and modernization of the education system Pesantren Salafiyah an effort to transform schools from the education system to the dichotomy of integral education so that modernization is the expansion of the education system and schools learning, not eliminate, the treasures of Islamic education. Pesantren is not in a hurry to transform itself into a (modern) general educational institution, nor does it persist with its traditional system. However, how policies or strategies are implemented to accommodate these two elements (traditional and modern), of course, must be carefully reviewed.

Efforts to reorganize the pesantren education system, at least the sides of the pesantren can be selected in two layers, first, the permanent side, the pesantren has the potential, namely the basic elements (Kiai, santri, classical 
books, dormitories, and mosques) must be maintained as the identity of the pesantren. Second, the temporal side namely the instrument element that is open to outside influences and always carries out a process of adaptation, selection, and environmental development that has contributed to the dynamics of the intellectual tradition of educational institutions.

\section{Designing Quality Education in Pesantren Salafiyah}

The problem of educational institutions both formal and non-formal is regarding the quality or quality of educational outcomes. Quality has become an undeniable necessity. Quality is an important indicator of the effectiveness of educational institutions. Quality in education requires a commitment to satisfied customers and a commitment to creating an environment that allows academics to do their best. For the design of the quality of pesantren education to achieve optimal results, strong leadership is needed, has a clear vision and mission, and can translate both into policy formulations and measurable goals by creating a work climate and atmosphere that empowers employees to do what they can. Best (Nafi, 2007).

In addition, a transformational leader is also needed, which according to Timpe in Nafi is defined as a leader who can create the shadow of the masses, which is to have an ideal and effective picture of the future of the pesantren, which can satisfy all stakeholders, and can mobilize the commitment of all pesantren residents to realizing the image into reality and able to institutionalize change, so that the boarding school becomes qualified according to or exceeding the wishes, needs, and expectations of its customers (Nafi, 2007).

Transformational pesantren leadership is identified and associated with having the ability to create a shadow of the future, namely having an ideal and effective picture of the future of the pesantren and being able to satisfy all stakeholders, to be able to mobilize the commitment of the pesantren community to realize the picture and satisfy the customer into a reality and be able to institutionalize change. In the end, the education of the pesantren will be of quality according to or exceed the wishes, needs, and expectations of its customers (Mulyadi, 2010).

Curriculum reform is also an important part of the education program. The target to be achieved is not merely to produce learning materials, but rather to improve the quality of education. The curriculum can provide a positive learning experience for students, both in the form of learning materials, environmental conditions of the pesantren, teacher figures, patterns of interpersonal interaction, and the culture in the pesantren (Baharuddin and Makin, 2010). The hope now is Pesantren Salafiyah to adopt common knowledge to his students, but also retaining the teaching of classical texts 
which is an attempt to continue the main objectives of the educational institutions, namely educational scored clerics loyal to the traditional notions (Bawani, 1998).

The design of the quality of pesantren education must begin by reformulating the educational curriculum in an integrative and comprehensive manner. As a wealth of tradition, pesantren is also advised to open opportunities for transformative and emancipatory synergies for community empowerment. The strategic side of pesantren which can accommodate all age, social, economic, cultural, and intellectual levels is the main consideration for the formulation of the educational curriculum. The formulation of the pesantren education curriculum must reflect a professional and proportional balance in the needs of students between the world and the hereafter, mind, and heart, physical and spiritual, as well as self-potential (internal) and environmental potential (external).

Therefore, curriculum development of Pesantren Salafiyah future there should be efforts to improve on the weaknesses that were found previously. Like the curriculum Pesantren Salafiyah consists of a nationally accepted curriculum and curriculum aligned with state and environmental requirements and characteristics for the educational unit concerned. ${ }^{1}$ Education curriculum Pesantren Salafiyah must combine education boarding school a traditional and formal education, if the two are combined, it will be able to raise output Pesantren Salafiyah a quality that is reflected in the attitude aspirational, progressive and not bound, so that students can quickly adapt in every form of change in civilization and can be well received by the community because it is not exclusive and has ready-to-use capabilities.

\section{Conclusion}

To make it easier to understand this research, the researchers make the following conclusions: first, pesantren as a religious institution today, still teaches and spreads the knowledge of the traditional Islamic religion. However, modern boarding also continue to develop, where pesantren do not only teach religion but also teach general sciences, skills, and so on. Second, the ability to lodge Pesantren Salafiyah make accommodations and certain concessions to find a pattern that he considers precise enough to face the modernization and change is increasingly rapid and broad impact without sacrificing the essence and basic things more in the existence of pesantren, so Pesantren Salafiyah still exist in the midst the hustle and bustle of modernizing Islamic education. Third, Pesantren Salafiyah must cultivate a proper appreciation of all developments that occur in the present and future, so that

${ }^{1}$ Agus Maimun and Agus Zaenul Fitri,Excellent Madrasah, Alternative Institutions in the Competitive Era (Malang: UIN Maliki Press, 2010), 54 
it can reproduce prospective ulama who are broad-minded, while also being committed to maintaining their traditional functions. Fourth, with a strong desire and enthusiasm to advance the Pesantren Salafiyah education system, the Pesantren Salafiyah curriculum must move from its traditional form and be constructed into a modern curriculum.

\section{References}

\section{Books and Research Results}

Abdullah. (2003). Kajian Historis Lembaga Pendidikan Pesantren. Jakarta: Bulan Bintan.

Arifin, M. (1993). Kapita Selekta Pendidikan Islam dan Umum. Jakarta: Bumi Aksara. Azra, Azyumardi. (2012). Pendidikan Islam: Tradisi dan Modernisasi di Tengah Tantangan Milenium III. Jakarta: Kencana.

Baharuddin dan Moh. Makin. (2010). Manajemen Pendidikan Islam, Transformasi Menuju Sekolah/ Madrasah Unggul. Malang: UIN-Maliki Press.

Bawani, Imam. (1998). Tradisionalisme dalam Pendidikan Islam. Surabaya: al-Ikhlas.

Creswell, J.W. (1998). Qualitatif Inquiry and Research Design. California: Sage Publication.

Djamas, Nurhayati. (2009). Dinamika Pendidikan Islam di Indonesia Pascakemerdekaan. Jakarta: Rajawali Pers.

Hasbullah. (1999). Sejarah Pendidikan Islam di Indonesia: Lintasan Sejarah Pertumbuhan dan Perkembangan. Jakarta: PT Raja Grafindo Persada.

Hasbullah. 2006). Kapita Selekta Pendidikan Islam. Jakarta: PT. Remaja Grafindo Persada.

Luthans, Fred. (2006). Perilaku Organisasi. Edisi 10. Yogyakarta: ANDI.

Mulyadi. (2010). Kepemimpinan Kepala Sekolah; Dalam Mengembangkan Budaya $M u t u$, Malang: UIN Maliki Press.

Nafi, M. Dian, et.al. (2007). Praksis Pembelajaran Pesantren, Yogyakarta: Institute for Training and Development.

Salim, Agus. (2001). Teori dan Paradigma Penelitian Sosial: Dari Denzim Guba dan Penerapannya, Yogyakarta: Tiara Wacana.

Surachmad, Winarno. (1970). Dasar dan Teknik Research: Pengantar Metodologi Ilmiah. Bandung: Tarsito.

Sutrisno, Edy. (2013). Budaya Organisasi. Jakarta: Prenadamedia Group.

Suwito dan Fauzan. (2004). Perkembangan Pendidikan Islam di Nusantara. Bandung: Angkasa.

Yasmadi. (2002). Modernisasi Pesantren: Kritik Nurcholis Madjid Terhadap Pendidikan Islam Tradisional. Jakarta: Ciputat Press. 
Asrizal Saiin

\section{Legislation}

Keputusan Direktur Jenderal Pendidikan Islam Nomor 3543 tahun 2018 tentang Petunjuk Teknis Penyelenggaraan Pendidikan Kesetaraan Pada Pondok Pesantren Salafiyah.

PMA No. 31 Tahun 2000 tentang Pendidikan Pesantren.

Undang-Undang Nomor 18 Tahun 2019 Tentang Pesantren. 